\title{
Development of Writing Text Description Learning Modules Based on Scientific Approach Class VII Junior High School
}

\author{
Aprijon $^{1 *}$, Atmazaki ${ }^{1}$, Y Asri ${ }^{1}$ \\ \{aprijonmalano@yahoo.co.id*\} \\ ${ }^{1}$ Faculty of Language and Art, Universitas Negeri Padang, Padang, \\ Indonesia
}

\begin{abstract}
The research aims of this study is to describe the process of development of learning modules writing text description based on valid, practical, and effective scientific approach used by class VII students. The subject of this research is 32 students of class VII.1 SMPN 1 Batang Anai. Data of the research consists of qualitative and quantitative data. Qualitative data is collected through filling validation and practicality module questionnaire. Quantitative data is obtained from students learning outcomes in writing text description learning. Result of this research shows that learning modules writing text description based on scientific approach produced is valid, practical, and effective. It is proven by the results of validity, practicality, and effectiveness module. Module validity by experts is obtained based on the module validity value of $88.63 \%$ so that the module is very valid category. Module practicality is obtained based on the practicality of students at the one-on-one evaluation stage of 79.63 with the practical category, the practicality of the teacher at the one-on-one evaluation stage is $92.50 \%$ with a very practical category, practicality of students at the small group evaluation stage of $92,05 \%$ with a very practical category, the practicality of students at the large group trial stage amounted to $89.29 \%$ with a very practical category. The effectiveness module based on the results of the performance test is $80 \%$ of students get complete grades $(>71)$ with a success percentage of 87.03 with the predicate B so that the category is very effective.
\end{abstract}

Keywords: module development, text description learning, scientific approach

\section{Introduction}

Education is a conscious and planned effort to create a learning atmosphere and learning process so students actively develop their potential to have religious spiritual strength, self control, personality, intelligence, noble character, and skills needed by themselves, society, nation and country. Educational planning begins with the formation of a national education curriculum. This time, the national curriculum has been implemented, it is called the curriculum 2013 after undergoing several revisions which are improvements from the previous curriculum. The fundamental changes made in the curriculum 2013 include four educational standards, namely: Standard Competency for Graduates, Core Competency Standards and 
Basic Competencies, Process Standards and Assessment Standards. This change also has implications for changes in learning patterns and the structure of instructional materials.

Curriculum 2013 learning is basically student-oriented learning. Students must be the subject of learning and able to learn independently from various learning resources [1]. Children are placed as learning subjects who try to learn on their own, not only receive information from the teacher and try what students learn according to their interests, talents, and level of development [2].

Teaching material is a component of learning that most influences what actually happens in the learning process. Teaching materials can be in the form of books, print and electronic media, the environment, or other relevant learning resources. Teaching materials also help the learning process to deliver subject matter. Thus, the teacher as an education facilitator must be able to provide teaching materials that are in accordance with the demands of the curriculum and the needs of students [3].

Based on the results of the reflection of Monitoring and Evaluation on the implementation of the curriculum conducted by the Ministry of National Education in 2014, the teachers still had difficulty implementing the curriculum because of the lack of facilities and infrastructure available at the school. Teaching materials used in learning are not innovative and not in accordance with the curriculum 2013. The textbook used by the teacher is a textbook given by the education office. The teacher has not been able to make his own teaching material as a complement to the book [4]. In addition, student handbooks are not relevant to the environment around students, examples that are shown not to be close to the student environment [5].

Based on the results of the researcher's observation on February 5th, 2017 on the value book of an Indonesian language teacher, Ms. Sri Pujianti, Daily Text Learning Values Description in class VII of SMP Negeri 7, data obtained only 15 people from 34 students who received complete grades. The data shows that learning has not been effective. That is, learning carried out with the media and available learning resources cannot yet realize the principle of complete learning. The number of students who complete or reach the Minimum Completion Criteria (KKM) limit has not reached $80 \%$.

Based on these data, one of the efforts that can be done to improve learning outcomes is to create teaching materials in the form of modules as a complement to student textbooks. Modules can be designed according to the needs of students [6]. Examples can be made based on an environment that is close to student life so that it is easy to understand. Furthermore, The module has the advantage of being able to make students independent and enjoyable learning because the modules are systematically arranged and there are associations, the use of various media, active student participation, direct reinforcement, and supervision through evaluation strategies [7]. Learning with modules is very relevant to the principles of learning outlined in the Curriculum 2013 process standards.

There are several reasons for the importance of developing modules based on the scientific approach to text description learning in class VII of Junior High School. First, in terms of students, valid, practical, and effective teaching materials are needed. This is in line with the teacher's professional obligations to develop teaching materials, one of them is a module for classroom learning as stipulated in the teacher's Professional Professional Development guidebook. Moreover, until now there is no module available for learning to write description texts in schools.

Second, in the curriculum 2013 (K13) the description text writing skill is one of the Basic Competencies that must be mastered by junior high school students before being declared graduated from the education unit. This Basic Competencies is in class VII in the first place in 
the Minister of Education and Culture number 37 of 2018 regarding Basic Competencies junior high school.

Third, in terms of content, the text of the description is a supporting text for several types of text. Text description can be part of narrative text [8]. Competence in writing description text is an essential competency in text-based language learning. This competency is important and is a preliminary material for mastering other competencies such as writing short stories, reports, and so on.

Fourth, the scientific approach is one of the approaches suggested in the curriculum 2013. The preferred learning model in the implementation of the Curriculum 2013 is inquiry based learning, discovery learning models, project-based learning models (PjBL), and problem based learning models (PBL) [9].

Formulation of the problem in this research is how is the process of development the learning module writing description text based on scientific approach class VII of junior high school which is valid, practical, and effective? Meanwhile, the purpose of this study is to describe the process of development learning module writing description text based on scientific approach that is valid, practical, and effective from class VII of junior high school.

\section{Method}

This type of research is research and development. The development model used is the Plomp model (initial investigation, design, realization/construction, testing, evaluation and revision, and implementation) [10]. The subjects of this study were 32 students of class VII.1 in SMP 1 Batang Anai. The research data consists of qualitative and quantitative data. The research instruments were in the form of questionnaires, observation sheets, interview guide sheets, and tests.

\section{Result and Discussion}

The module developed is a module that has been categorized as valid, practical, and effective. Therefore, according to the chosen development model (Plomp model), to obtain a quality module, a series of testing, evaluation and revision activities are carried out on product realization / construction. The activity includes five main activities, namely: (1) self evaluation, (2) expert review, (3) one on one evaluation, (4) small group evaluation, and (5) field testing [10].

\subsection{Self Evaluation}

The main activity carried out at the review and revision stage is to re-examine the modules that have been produced, both from the aspects of content, language, presentation, and graphics. The goal is to get a better and perfect prototype module. The activity is carried out before the module is validated by experts.

In general, the errors seen by the author at the stage of self evaluation are typing errors, spelling, and punctuation. Typical mistakes, for example, should be "kawasan" written "kawasa". Spelling errors, for example, in a written module, "detil" should be written "detail". The punctuation error occurs in the details section of the indicator, which is not giving a dot at the end of each detail. In addition, the use of exclamation marks is also used. For example, in the detailed instructions for using a module that should use an exclamation point, but not an exclamation mark. Based on the examination itself, improvements have been made accordingly. In addition to self-examination, evaluations were also carried out by 
practitioners, namely Indonesian language teachers who were members of the Indonesian Language Middle School Teacher Discussion Forum in West Sumatra province.

\subsection{Expert Validation}

Module validation is carried out by two experts, lecturers of Indonesian Language and Literature Education by filling out a validation sheet in the form of a questionnaire consisting of four aspects of assessment, namely: (1) Aspects of Feasibility of Content, (2) Language Aspects, (3) Presentation Aspects, and (4) Kegrafikaan aspects. Based on the analysis of the answer validator on the validation sheet, the results of validity are obtained as follows.

Table 1. Results of module validation by experts

\begin{tabular}{llccc}
\hline No. & Rated Aspect & $\begin{array}{l}\text { Score } \\
\text { Gain }\end{array}$ & $\begin{array}{l}\text { Validity } \\
(\boldsymbol{\%})\end{array}$ & Categories \\
\hline 1. & Content feasibility & 164 & 82.00 & Very valid \\
2. & Linguistics & 60 & 93.75 & Very valid \\
3. & Presentation & 146 & 91.25 & Very valid \\
4. & Integrity & 56 & 87.50 & Very valid \\
& Overall module validation & 106.5 & 88.63 & Very valid \\
\hline
\end{tabular}

\subsection{One to One Evaluation}

Individual evaluation of learning modules in skilled Indonesian writing texts Descriptions of class VII were conducted at the first meeting in the learning activity to recognize the description text. Learning activities carried out by students are to study the object, purpose, and type of text description by using the learning module to write description text based on the scientific approach provided by the teacher / writer. In this activity, students are asked to identify objects, objectives, and types of text by reading and working on the exercises available in the module. In general students are able to do the exercise. Students are able to identify objects, objectives, and types of description text. In addition, students have also been able to explain the characteristics of objects, objectives, and differences in each type of description text.

At the end of the learning session of the first meeting, students were given a questionnaire to see the practicality of the module used by students in learning. Students are asked to fill out a questionnaire according to the instructions stated on the questionnaire. Recapitulation of module practicality questionnaire by students is analyzed based on aspects of ease of use and time spent. BThe results of the practical questionnaire analysis of modules by students in the one to one stage as shown in table 2.

Table 2. Results of practicality questionnaire analysis by students

\begin{tabular}{llccc}
\hline No. & Assessment Aspects & $\begin{array}{c}\text { Total } \\
\text { Score }\end{array}$ & Practicality (\%) & Categories \\
\hline 1. & Ease of use & 145 & 86.31 & Very practical \\
2. & Time use & 27 & 75.00 & Practical \\
& Overall module practicality & 172 & 79.63 & Practical \\
\hline
\end{tabular}


In addition to providing questionnaires, at the end of the first meeting interviews were also conducted with students informally to get responses and suggestions from students as module users. Based on interviews with students at the one-on-one evaluation stage, responses were obtained that generally the modules produced were quite good but there were still some things that needed to be improved. Improvements are made based on student responses as shown in the following table 3 .

Table 3. Response and suggestions from students

\begin{tabular}{lll}
\hline No. & Student Feedback & Revised Result \\
\hline 1. & The image on the module cover is too big, & Change the image display and add \\
it needs some variations to make it more & & $\begin{array}{l}\text { variations to the cover to make it } \\
\text { more attractive }\end{array}$ \\
2. & $\begin{array}{l}\text { Pictures in the module are still lacking, it } \\
\text { needs to add images to the text that is still }\end{array}$ & $\begin{array}{l}\text { Add pictures of cats and tigers in } \\
\text { text } 4 \text { "Cats, Predatory Animals } \\
\text { that are Familiar with Humans". }\end{array}$ \\
empty & There is a typing error & Correct all typing errors
\end{tabular}

In addition to giving questionnaires and interviews with students, teachers who use the module are also given a questionnaire to assess the practicality of the module, then informally interview the teacher to ask for comments and suggestions about the module students use. Teacher questionnaire module consists of 18 statements consisting of 5 statements about module ease of use, 4 statements about module form, 3 statements about module content, 3 statements about the benefits of applying modules in learning, and 3 statements about the practicality of applying modules in learning. Furthermore, based on the results of the module practicality questionnaire, the teacher carried out an analysis based on aspects of ease of use and time spent. The results of the module practicality questionnaire analysis by the teacher can be seen in table 4 .

Table 4. Results of practicality questionnaire analysis by teacher

\begin{tabular}{llccc}
\hline No. & Assessment Aspects & $\begin{array}{c}\text { Total } \\
\text { Score }\end{array}$ & Practicality (\%) & Categories \\
\hline 1. & Ease of use & 56 & 93.33 & Very practical \\
2. & Time use & 11 & 91.67 & Very practical \\
& Overall module practicality & 67 & 92.50 & Very practical \\
\hline
\end{tabular}

At the end of the first meeting activities were conducted informally interviews with teachers who taught in class VII.1 to ask for their responses and suggestions. Based on the suggestions from the teacher, improvements were made as shown in table 5.

Table 5. Response and suggestions from teacher

\begin{tabular}{lll}
\hline No. & Feedback & Revised Result \\
\hline 1. & $\begin{array}{l}\text { Module cover is too dominant in blue, it's } \\
\text { better to add red or yellow to make it } \\
\text { more alive and attractive }\end{array}$ & $\begin{array}{l}\text { The color design of the module } \\
\text { cover is changed by inserting the } \\
\text { yellow color in the variation of the } \\
\text { image. }\end{array}$ \\
2. & Pictures are still lacking. Need to add & In the text 4, add the pictures of \\
\hline
\end{tabular}




\begin{tabular}{lll}
\hline images, especially in text 4. & cats and tigers. \\
3. There is still typing error in text 2 about & $\begin{array}{l}\text { Corrected typing and writing of } \\
\text { the dots and writing of sequence numbers. }\end{array}$ & prepositions. \\
\hline
\end{tabular}

\subsection{Small Group Evaluation}

Small group evaluation module is carried out at the second meeting in learning activities explaining the contents of the description text. Learning activities carried out by students are reading texts, arranging questions, determining the answers to questions, composing sentences based on the answers to questions, making concept maps, and rearranging the contents of the text through discussion and presentation activities. At the end of the learning activity, students are asked to do exercise, which is to compile text based on concept maps available in the module. In general students are able to do the exercise.

In addition, at the end of the activity ten students consisted of three low-ability students, three moderate-capable students, and four high-capable students were asked to fill out the module practical questionnaire by students provided by the author. The results of the questionnaire were analised based on aspects of ease of use and time used. The results of the second analysis of the practical aspects of the module are explained in the following table 6 .

Table 6. Results of practicality questionnaire analysis by student

\begin{tabular}{llccl}
\hline No. & Assessment Aspects & $\begin{array}{c}\text { Total } \\
\text { Score }\end{array}$ & Practicality (\%) & Categories \\
\hline 1. & Ease of use & 517 & 92.32 & Very practical \\
2. & Time use & 109 & 90.83 & Very practical \\
& Overall module practicality & 680 & 92.05 & Very practical \\
\hline
\end{tabular}

\subsection{Large Group Trial (Field Test)}

A large group test (Field Test) module was conducted to test the module's practicality and effectiveness. The activity was carried out in fourth meeting of 32 students of class VII.1 in SMP Negeri 1 Batang Anai. At the end of the learning activity, each student is asked to work on test, which is writing text based on the object that has been set. In general students are able to do the exercise.

After learning the fourth meeting ends, students are asked to fill out a questionnaire according to the instructions provided. The results of the practical questionnaire were analised based on aspects of ease of use and time spent. Thus, based on the results of a large group trial that the module developed thanks to the theory is very practical, it is feasible to use for learning to write description text. The results of the second analysis of the practical aspects of the module are explained in the following table 7.

Table 6. Results of practicality questionnaire analysis by student

\begin{tabular}{lllll}
\hline No. & Assessment Aspects & $\begin{array}{l}\text { Total } \\
\text { Score }\end{array}$ & Practicality (\%) & Categories \\
\hline 1. & Ease of use & 1618 & 90.92 & Very practical \\
2. & Time use & 339 & 88.28 & Very practical \\
& Overall module practicality & 1957 & 89.29 & Very practical \\
\hline
\end{tabular}


In addition, at the end of the learning activities performance tests are part of the module evaluation activities at the phase of the large group trial (Field Test evaluation) which aims to see the effectiveness of the title used in the learning process in writing description text. Students are asked to write a description text based on the performance test rubric provided by the teacher. After students work on performance tests, student work results (description text) are assessed using the assessment rubric provided.

The assessment instruments contained in the module function as self-assessments [11]. Through the performance test assessment sheet presented in the module, students can measure their skills in writing description texts. Based on the results of the performance test assessment, it can be stated that the Skilled Writing Text module is effective. This can be seen from the results of the assessment of the performance of 32 students, namely 10 students get an A (>90-100), 17 students get a B (> 81-90), 5 students get a C (> 71-81), and no student gets a $\mathrm{D}$ or is taken by the minimal completeness criteria $(<71)$. Thus it can be stated that the Skillful Writing Text module Description of Class VII Based on the Scientific Approach developed has been effective because based on the test classical learning completeness has been achieved, ie $80 \%$.

\section{Conclusions}

Implementation was carried out on 34 students of class VII.1 of SMP Negeri 1 Batang Anai to improve the module so that final products were produced which were ready to be disseminated at the school to be used as teaching materials in the following year's learning process by teachers and students. Based on data from the results of a large group trial on the practicality and effectiveness of the module, interviews were conducted with the teachers who had been asked as observers. From the observers obtained information that as a whole the module developed has met the standards and can be used for learning to write description text. However, there are still parts that need to be revised, namely in the activity section of writing description text. Based on the teacher's suggestion, it is better to learn to write texts that consist of setting objects, arranging the framework for compiling instruments and observing objects, and revising the text in the form of group work to create a learning society to develop collaborative abilities. Therefore, instructions need to be written so that students form study groups for these activities. Based on the suggestions from the teacher, a module revision was made so that the final product was ready to be distributed to various related parties, teachers, students, school libraries, and Indonesian language subject teachers who joined Deliberation Forum for West Sumatra Province Junior High School Subject Teachers in the form of softcopy and print out.

\section{References}

[1] H. Pratiwi, Panduan pembelajaran untuk sekolah menengah pertama. Jakarta: Kemendikbud, 2016.

[2] W. Sanjaya, Strategi pembelajaran berorentasi standar proses pendidikan. Jakarta: Kencana, 2008.

[3] Supriano, Materi pelatihan guru implementasi kurikulum 2013. Jakarta: Kemendikbud, 2016.

[4] I. Rosida, "Pengembangan modul berbasis scientific approach sebagai bahan ajar pendukung implementasi kurikulum 2013 pada materi pokok penggunaan jurnal khusus di SMK Negeri Mojoagung," J. Pendidik. Akutansi, vol. 3, no. 2, 2015.

[5] N. L. G. R. P. Bintari, "Pembelajaran bahasa indonesia berdasarkan pendekatan saintifik (problem based learning) sesuai kurikulum 2013 di kelas VII SMP Negeri 2 
Amlapura," J. Progr. Pascasarj. Univ. Pendidik. Ganesha Progr. Stud. Pendidik. Bhs. Indones., vol. 3, 2014.

[6] Sumiati and Asra, Metode pembelajaran. Bandung: Wacana Prima, 2007.

[7] H. Darmadi, Kemampuan dasar mengajar: landasan konsep dan implementasi. Bandung: Alfabeta, 2010.

[8] I. Marahimin, Menulis secara populer. Jakarta: Pustaka Jaya, 2004.

[9] Sufairoh, "Pendekatan saintifik dan model pembelajaran K-13," J. Pendidik. Prof., vol. 5, no. 3, 2016.

[10] T. Ploomp, Educational design research: an intruction. enschede: slo: netherlands institute for curiculum development, 2013.

[11] Asyar, Kreatif mengembangkan media pembelajaran. Jakarta: Gaung Perkasa Press. 